\title{
Skin Squamous Cell
}

National Cancer Institute

\section{Source}

National Cancer Institute. Skin Squamous Cell. NCI Thesaurus. Code C33562.

A flat, scale-like epithelial cell found on the outer covering of the body. 